MENDES, Cândido. A Presidência afortunada - depois do Real e antes da social-democracia. Rio de Janeiro : Record, 1998.

\title{
PROMESSA, QUEDA, REDENÇÃO: A PRESIDÊNCIA AFORTUNADA NA VISÃO DECÂNDIDO MENDES
}

\author{
Gildo Marçal Brandão \\ Universidade de São Paulo
}

Como a pessoa e a ação do governante atual costumam provocar amores e ódios com a mesma intensidade, é difícil encontrar uma análise distanciada da conjuntura e equilibrada o suficiente para nos ajudar a compreender a natureza das transformações em curso e as implicações históricas, positivas ou negativas, da política que vem sendo executada. Desapaixonada certamente a do professor Cândido Mendes não é, mas salvo engano, as 100 primeiras páginas de seu recém publicado A Presidência afortunada — depois do Real e antes da social-democracia, devem constituir a mais ambiciosa tentativa até agora empreendida por um cientista político de examinar a figura e a performance do intelectual e do político profissional Fernando Henrique Cardoso. Só isso seria suficiente para assegurar o seu interesse, não fosse o autor um intérprete ousado e, sob certos aspectos, original do processo político em curso.

A segunda parte do livro do reitor da Universidade Cândido Mendes, do Rio de Janeiro, é composta por artigos publicados em alguns dos principais jornais do país. Apesar da linguagem barroca, plena de metáforas e construções estilísticas retorcidas, que por vezes torna a leitura difícil, não há dúvida de que temos diante de nós um texto cheio de percepções, hipóteses e análises sugestivas.

Trata-se, é certo, de um livro de alguém fascinado pela personalidade intelectual e política de Fernando Henrique Cardoso, de quem reconstrói sinteticamente a trajetória desde os tempos da USP e da circulação acadêmica internacional até a adesão ao MDB, a senatoria e a Presidência; e a quem considera "um Presidente que exorbita os quadros normais de uma expectativa creditável ao maior desempenho de uma persona brasileira" e, num século tremendamente "severo e avaro" quanto à qualidade dos governantes, comparável favoravelmente à figuras como Malraux e De Gaulle, Poincaré e Woodrow Wilson, Mitterrand e Léon Blum, todos de alguma forma doublés de acadêmicos e políticos.

Não se conclua daí, apressadamente, que temos um livro apologético do presidente e do seu governo. Ao contrário, a análise de Cândido Mendes é extremamente crítica, marcada por uma tensão enorme, na qual tenta surpreender a lógica da atuação de Fernando Henrique Cardoso e, ao mesmo tempo, confrontá-la com suas próprias promessas e o seu próprio discurso. O resultado da "Presidência afortunada" é, como ele próprio reconhece, trágico, contendo a hipótese não só do fracasso, mas sobretudo do pior tipo de acusação que é possível fazer a um político, sobretudo aquele que quer ficar para a história, o de "ser culpado pelo que não fez".

O Fernando Henrique Cardoso que emerge da escrita de Cândido Mendes não é um "rei-filósofo" nem um “intelectual no poder", mas um político profissional dotado de consciência histórica, alguém plenamente consciente dos seus objetivos e do preço a pagar para alcançá-los, mas, por isso mesmo, solitário, consciente da tragicidade de sua posição, que tenta racionalizar como pode.

Mendes aponta o tempo todo a contradição entre o discurso e a prática, isto é, aceita as razões alegadas pelo presidente, que sempre negou ser "neoliberal" e ter abandonado a esquerda (como um Rei Sol, sugere, o político parece dizer "a esquerda sou eu"), mas mostra como a lógica da operação de seu governo acabou por levá-lo a executar o programa neoliberal e, mais do que isso, a assumi-lo até às últimas consequiências, como no malthusiano tratamento dispensado à questão social e ao movimento operário, ao salário e ao desemprego, na disposição de oferecer todas as garantias possíveis aos investidores estrangeiros, no 
bolchevismo de direita (digamos assim) com que está efetivando o desmonte do aparelho de Estado etc. A tragédia vem de que algumas dessas reformas são necessárias, precisavam ser feitas, mas o que está sendo feito é uma negativa completa do que teria sido o projeto histórico peessedebista original.

Além da Presidência, o exame da natureza e da situação do tucanato é outra das contribuições do livro. Ostensivamente simpático ao PT e defensor de uma virada de centro-esquerda no segundo mandato de FHC, Cândido Mendes não hesita em cobrar do presidente o social democrata que não conseguiu ser, assim como considera que está hipotecado ao Partido dos Trabalhadores, em contradição com o seu revolucionarismo inicial, acabar sendo a social democracia que o PSDB não chegou a realizar.

Nesse sentido, trata-se de um livro de alguém que se tornou uma avis rara, quem sabe um estranho no ninho, como notou o professor Luiz Eduardo Soares, do Iuperj, numa resenha publicada no Jornal do Brasil, um peessedebista de esquerda deblaterando contra a lógica que levou seu partido não apenas a fazer uma aliança tática (considerada necessária e razoável) com a liberal democracia, mas a comprar por inteiro o pacote programático dos liberais, perdendo identidade no processo; e a tornar-se não o pólo ideológico que ambicionou ser nem um autêntico "partido de governo", mas simplesmente o "partido do presidente", e, como tal, constrangido a cerrar fileiras automaticamente, a funcionar como moeda de troca, sempre passível de ser sacrificado no altar da lógica aliancista. Dadas as circunstâncias, parece tratar-se de um caminho sem volta tanto para o governo como para o partido. Sem volta a não ser que na undécima hora o presidente...

É essa expectativa de salvação, essa confiança na fortuna e na virtude do príncipe quando tudo o mais desfalece que tensiona a análise de Cândido Mendes até o limite. Considerando que a precariedade das instituições brasileiras e a rapidez com que o exercício do poder desgasta, exacerbam o papel do líder e tornam a qualidade da liderança a variável decisiva do processo, o analista mantém a aposta na capacidade demiúrgica do grande ator, como se estivesse sempre à espreita de que ele contraditasse as suas teses, demonstrasse nos fatos que elas estavam erradas, reencontrasse as suas próprias origens e levasse o país noutra direção.

Promessa, queda, redenção, essa parece ser a estrutura ternária da construção de Cândido Mendes. A dúvida aqui é se o elogio da virtude e a esperança da redenção não transfiguram demasiado o argumento, se o senso da tragédia - o momento da análise concreta - não se esvai antes do tempo. Num determinado momento o autor vaticina hegelianamente que "a História tolera demoras mas não se demite: poderá caber ao PSDB realizar o neoliberalismo, como ao PT a social-democracia”. Pode ser. Mas se é assim, então não há como escapar analiticamente da questão formulada por Friedrich Engels em seu estudo sobre As guerras camponesas na Alemanha: o pior que pode acontecer a um chefe de partido chegado prematuramente ao poder é se ver forçado, pela força das circunstâncias, a realizar o programa dos outros. O que realmente pode fazer acha-se em contradição com toda a sua atuação anterior, o que deve fazer não é realizável. Quem ocupa esta posição ambígua está perdido e acaba sendo forçado a representar não os seus, mas aqueles chamados a dominar no momento.

Provavelmente por boas razões - ótimo para o historiador, esse argumento poderia ser péssimo para o político - Cândido Mendes não dá esse passo, sequer o coloca. Ao contrário, o elogio fúnebre que escreve, para usar os seus próprios termos, não é um réquiem, o qual só se executa para os definitivamente extintos, mas uma pavana, que se entoa para os quase defuntos, mas que ainda têm a possibilidade de ressurgirem das cinzas, qual uma fênix.

Recebido para publicação em agosto de 1999.

Gildo Marçal Brandão (gmb@usp.br) é Professor do Departamento de Ciência Política da Universidade de São Paulo (USP) e pesquisador do CNPq. 